\title{
Beyond Hand Waving: Indices For Hymn Leading in Corporate Christian Worship
}

\author{
Adeolu Ogunleye ${ }^{1}$ iD \\ ${ }^{1}$ Good News Baptist Church, Surulere, Lagos, Nigeria.
}

\begin{abstract}
The paper examines the significance of the selection, planning, and factors that affect the leading and singing of hymns in corporate Christian worship. While myriads of scholarly literature abound on hymnology, through bibliographies and an in-depth library search, the paper seeks to discuss the guidelines that engender the leading of congregation hymns and methods required for a dynamic leading of hymns. The research findings reveal that in some Nigerian churches where there are no trained music ministers, many untrained song leaders merely stand before the congregation to announce the hymns for the congregation to sing without performing a leadership role. Others merely stand to wave a hand. Leading congregational hymns requires training and vivaciousness in skill application. The three major areas of focus include planning, leading, and congregational response to hymn singing. The paper concludes that planning and selection of hymns are both spiritual and intellectual exercises that involve basic knowledge of the rudiments of music. The research will help the church musicians and academics in further research into church music and congregational hymn singing.
\end{abstract}

Keywords: Song Leader, Hymn, Hymnody, Worship, Corporate Christian Worship

Correspondence:

Adeolu Ogunleye

Email: adeoluogunleye@yahoo.

com

Publication History

Received 24th May, 2021,

Accepted 20th July, 2021,

Published online 13th September, 2021.

(C) 2021 The Author(s). Published and Maintained by Noyam Publishers.

This is an open access article under the CCBY license (http://creativecommons.org/licenses/by/4.0/).

\section{INTRODUCTION}

Christian music is often generally grouped into two namely: church, and gospel music. While Christian music serves as the mother of all songs sung by Christians, church music is for a liturgical purpose and worship. The gospel genre on the other hand is performed for many purposes which include aesthetic pleasure, religious ceremony purposes, and entertainment. Theologically speaking, gospel music is meant for the spreading of the good news of Jesus Christ. Given this, music occupies a dominant position in Christian worship. One notable fact is that Christian worship is largely characterized by various elements that include prayer, scripture reading, offering, homily, and music among others. Music plays a dominant role because virtually nothing exists in worship that cannot be executed through music.

Daramola's discourse on Christian music as a discipline $\mathrm{x}$-rays what Christian music is by noting that:

Christian music is a generic term that covers all types of music with Christian texts. Christian music as a religion has music-making as one of its practices from inception. During worship services, music plays an important role. Christian worship or service without music is just like a rainbow without colours. Take away singing from the church--- and the pews will be vacant and innumerable "music halls" and "entertainment houses" will sprout up. There is beauty, majesty; dignity, and even personal warmth in service or worship which only music can express. ${ }^{1}$

\footnotetext{
1 Yomi Daramola, "Christian Music as a Discipline: A Religious Appraisal of Christian Music In Nigeria Today". CyberJournal for Pentecostal- Charismatic Research, no. 7 Accessed May 14, 2021. https://guardian.ng>art>night-of-unlimited-praise-in-1
} 
This goes on to elucidate the role of music in worship. Paul the Apostle in Colossians 3:16 particularly alluded to three types of music for the church. In his statement, he recommended hymns, spiritual songs, and Psalms as the music for the church. Noting that a hymn is one of the expedient musical tools in worship, the paper precisely seeks to address the practice of hymn singing in the context of Christian worship, with specific attention on the keys to effective congregational hymn leading. The terms 'song leader' and 'hymn leader' are used interchangeably while the study is limited to the recipes for the hymn leaders especially those without basic knowledge of music rudiments and those with a low level of music literacy.

\section{Definition of Concepts}

\section{Song leader/ Hymn leader}

There are different titles used in different churches to depict the hymn leader. In some contexts, for example in the Nigerian Baptist denomination in which the researcher operates, the song leader is often a Pastor who is a Minister of music. Where the church has no Minister of music, the role is performed by the music director, choirmaster, or song leader. The title depends on the context. A song leader in a local church serves as the conductor of the congregational hymns. What a hymn leader stands to do is to guide the congregation in hymn singing. Conducting is the art of directing a musical performance, such as an orchestral or choral concert. It has been defined as "the art of directing a performance of an orchestra through the dedication of a conductor who utilizes gesture to set the tempo, and ensures phrasing where appropriate". ${ }^{2}$ Conducting involves the use of gestures to lead a singing group. While the conductor also conducts the choir, in this study, a song conductor or hymn leader is defined as the one who stands before the congregation during the hymn singing to direct the singing by the use of hand expressively and intelligently. ${ }^{3}$

\section{Worship}

Worship is fundamental to any religion and there are different definitions to it. Nevertheless, worship denotes "worthiness" or "acknowledgment of worth". ${ }^{4}$ Correspondingly, the idea of worship suggests the expression of the worthiness and acknowledgment of God. Christian worship can be classified into two: first, private worship, and second, corporate Christian worship. While private worship is carried out individually, corporate Christian worship is carried out in a group. Despite the differences in the context, hymns are appropriate in both private and corporate Christian worship. Since hymn leading often takes place in corporate Christian worship, the question is what is corporate Christian worship?

\section{Corporate Christian Worship}

According to Davidson, "corporate Christian worship is dramatic, dynamic, a dialogical encounter between the triune God of the Bible and His people in which God speaks and or acts to reveal Himself and His will and God's people respond to Him in appropriate biblical ways". ${ }^{5}$ It is worship performed by people in a group. It takes place as fellowship or in a church auditorium which could be in a large or a small group. Music is one of the aspects of worship through which response can be made to God. Worship music includes hymns, spiritual songs, and psalms. Davidson describes the Old Testament Psalms of the scriptures as examples of psalms singing and refers to hymns as probably composed songs like in the statements of Christological praise using Philippians 2:6-11 as an example. The 'spiritual songs" perhaps included at least spontaneous glossolalic melodies as stated in I Corinthians 14:14-16. For clarification, the contemporary choruses of praise can be categorized as spiritual songs. Hymns are called sacred songs, but the current hymns of the church that are harmonized have improved over the New Testament and early church hymns typologies that were entirely "one voice" or unison type. In this context, the hymn is considered one of the most important forms of music for worship. ${ }^{6}$

\footnotetext{
2 Michael Kenedy. Oxford Concise Dictionary of Music. (Oxford: Oxford University Press, 2007),n.p.

Alma Rohm. Music for the Church. (Ibadan: Dybis Limited, 1998), 163.

Femi Olajide, God is Hungry, Feed Him. (Abeokuta: Dareg Image, 2018), 50.

Paul Davidson, Come Let Us Worship. (Ibadan: Publication Department, Nigerian Baptist Convention.2002), 2.

6 Paul Davidson, The Place of Music in Dialogical Worship.1999 Ministers'Conference. (Ogbomoso: Nigerian Baptist

Theological Seminary, 1999), 28.
} 


\section{Hymn}

A hymn is a religious song or poem of praise to God sung during Christian worship, typically by the whole congregation. The term hymn is derived from the Greek word hymnos, "festive song or ode in praise of gods or heroes," used in the Septuagint (earliest Greek translation of the Hebrew Scriptures) to translate several Hebrew words meaning "song praising God."

Different literature on the history of Church music illustrates that hymns are part of the Christian musical heritage that has subsisted despite innumerable challenges that have confronted the church. Adeleke, submits that the earliest Christian hymns are mentioned by Paul in his letters. ${ }^{8}$ In light of this, a hymn is a song of worship or religious song in poetic and stanzaic form meant to praise God. On the contrary, it must be stressed that not all hymns today connote praise neither are all hymns vertical that is, directed to God. This proves that a relevant definition of hymn can preferably be deduced from the word of Paul in Ephesians 5:19 which refers to hymns as means of communication when he draws attention to "speaking to one another". Primarily, hymns are sung for a social and divine purpose. Thus, beyond praise to God, hymns could be an expression of prayer, belief, personal experience, and exhortation. ${ }^{9}$ Hymns are sacred songs that form the essential means by which the congregation expresses itself in worship.

\section{Hymnody and Hymnology}

To this end, it is needful to assert that there is a difference between hymnody and hymnology. Singing or composition of hymns is referred to as hymnody, while a writer of hymns is known as a hymnodist. A collection of hymns is called a hymnal or hymnary. A student of hymnody is called a hymnologist, and the scholarly study of hymns, hymnists, and hymnody is hymnology. ${ }^{10}$ Thus, hymnody involves hymn writing, hymn singing, or the collective hymn of a time, place or religion, or church. It is interesting to note that hymnody has a relationship with hymnology. The significant point is that hymnology centers on the scholarly study of religious songs, the hymn, and its many aspects with actual emphasis on the choral and congregational song. Ultimately, hymnody is the creation and practice of hymns and hymnology is the scholarly study. Hymnology is an obsolete meaning of performing hymns. The history and etymology of hymnody are that of late Latin hymnodia from the Greek word hymoidia, which implies to sing. Hymnology is a study that focuses on the historical and scientific study of the hymn. It studies both the textual and the musical aspects of hymns. ${ }^{11}$

\section{Theoretical Framework}

The paper is hinged on the theory propounded by Janvier captioned 'Leading People in Worship' which explains the great opportunities of congregational song leading. This profound discourse serves as the fountain and pedestal for hymn leading. To facilitate appropriate congregational hymn singing, the responsibilities of the hymn leader are of utmost importance. According to Janvier, the church needs a good song leader as:

There are many people leading church music who do not know how to bring spiritual life into a service. They stand in front of the people and sing along with them rather than leading in the music ministry. Youth complain that our services are dull. This can usually be laid at the feet of the song leader. It is important that the song leader lead the people. The song leader gives life to the meeting. A dull song leader usually means a dull service. A lively song leader usually means a lively service. ${ }^{12}$

The above statement gives credence to the need for a knowledgeable and vivacious hymn leader in worship.

\footnotetext{
Joe Carter, 9 Things You Should Know About Christian Hymns. Accessed May, 14, 2021, https://www.thegospelcoalition.org.>article>9-things... 2018).

8 Abel Adeleke, Parameter for Using Music in Worship. (Ibadan: Titles Publishers, 2014), 166.

9 Harry Eskew \& Hugh McElrath, Sing With Understanding. (Nashville, Tennessee: Broadman, 1995), ix.

10 Carter, 9 Things You Should Know About Christian Hymns.

11 "Hymnology". Encyclopedia.com. Accessed May 9, 2021, https://www.encyclopedia.com<religion>hymnology.

12 George Janvier. Leading the Church in Music and Worship. (Bukuru: African Act Textbooks, 2007), 53.
} 
This perspective is used to study the role of the song leader in hymn selection and leading in worship. There are measures for hymns selection. The pertinent question is what are the measures required in hymn selection? The study finds answers to the questions which to assert the responsibilities of the song leader as a worship leader. ${ }^{13}$

\section{Hymns Selection Questions}

1. Appropriateness question: Is it appropriate? It must be ensured that the hymns to use are relevant to the worship.

2. Sing-ability question: Is it sing-able? This is to confirm if the hymn is within the compass of the musical ability of the choir and the congregation. The tempo, rhythm, and key range must be considered.

3. Scriptural cum Doctrinal question: Is it scripturally true and doctrinally sound? It should be ensured that the hymns chosen are biblically okay and theologically accurate. The message should be clear and not monotonous.

4. Reverential question: Is it reverent? The words should convey a sense of God's presence.

5. Usefulness question: Is the song useful in the planned purpose of the worship service? It must be ensured that the hymns are useful because a hymn can be relevant but not useful in the worship service.

6. Attention question: Does the song move the singers to direct attention to God? The song must be able to direct the worshippers' attention to God in worship.

7. Quality question: Does the music have quality? The song should have good standard literacy musical expression.

8. Service theme question: Does the hymn support the theme of the service? The hymn needs to be in line with the theme of the worship service, especially in thematic worship. While not strictly advocating thematic worship, it is preferable to align with the theme and the message of the worship service. Prior knowledge of the sermon topic or the scriptural texts for the message is an additional advantage to hymns selection. Pondering on what the sermon could say about the Bible text, the likely inspiration that could help in selecting relevant hymns for the message.

9. Moreover, thinking about hymns that use the words and phrases found in the scriptural passage to be used for the sermon can also help in hymn selection relevant to the message and the service as a whole. This is where lectionary, hymnals, and hymns storybooks will be applicable, paripasu being a good Bible student. Sometimes, the hymn selection could be based on the occasion, festival, or season being celebrated. One must consider what the pattern of the service will look like.

Hymns are meant to elicit congregation participation. With the above considerations, good congregational participation can be enhanced in hymn singing. Hymn singing during corporate Christian worship becomes boring when the hymn leader lacks adequate understanding of the means to carry the congregation along. The hymn leader would need to reflect on certain basic guidelines to improve hymn leading and the singing of hymns by the congregation.

\section{Reflections on Leading of Hymns in Worship}

1. Let it flow: one of the basic things to do is to plan out how things will flow from one aspect to the other. Worship aspects need to be connected and not independent of one another. For example, it can flow from praise sessions to prayer or hymn singing, to the aspect of welcoming each other into announcements.

2. The element for transition: It is expedient to consider how one element ends and how the next will start to enhance a smooth connection. When transiting from one element to the other, brevity is required. For example, long Bible passages or comments should not be used as an introduction to congregational singing, it can be paraphrased.

3. For service, it is vital to embark on advance or long-range planning. To plan is to plan to succeed. Hymn leaders can think ahead, plan and arrange for the hymns to be used in the future.

\footnotetext{
13 "Worship Planning Process". Accessed April 3, 2018. http://worship.calvin.edu>resources.
} 
4. Strive for excellence every Sunday- it is necessary to give one's best each week and every service. Nothing less should be given to God.

\section{Suggestions / Recommendations}

At the crux of it all, to foster good hymn leading, the paper suggests that the hymn leaders in worship should always consider their congregational setting. Since congregational hymn singing is not a time for solo performance by the song leader, a song director is advised to be conversant with the congregation, how songs are performed with them, how they sing, and their normal response to songs. It is not advisable to use hymns that are not known by the congregation or that do not work with them except with the plan and intent to teach the congregation a new hymn or tune. Teaching would work well if it is relevant. Meanwhile, it is not for the best to outstretch the congregation by wasting precious time while the worship service itself is already a long one. Evaluating the setting and asking if the hymns will be relevant in the worship should not be undermined.

Similarly, it is needful for hymn leaders to have in mind God-centered songs rather than selecting all songs based on "self". While there is a place for horizontal songs in worship, selecting hymns that will glorify God, bring and prepare people to receive God's word, and stimulate encounters with God is critical.

Another essential factor to note is for the song leader to consider the instrumentalists in selecting hymns for worship. Instrumentalists should not be undermined, especially the organist. Bearing in mind the level of dexterity of the organist is necessary. Where the organist is not a proficient music reader, it is better to choose the hymns that the organist can play or give the organist to rehearse at least days before the service so that worship will not be marred by the wrong accompaniment.

Likewise, efforts should be made to always rehearse hymns with the choir. The choir is to rehearse the hymns to reinforce the hymn leader and the congregation during the worship service. One of the roles of the choir is to sing songs that ordinarily, the congregation may not be able to sing alone. Rehearsing hymns at least during the final practice saves from haphazard singing.

In addition, hymn leaders should have personal hymn singing rehearsals. Correct personal rehearsal is required for an excellent congregational hymn leading. The skill in song leading cannot be acquired by prayer and study alone, it comes by practice.

Hymn leaders should develop their level of hymn tune knowledge because it determines the dynamism that can be brought into hymn singing. The use of different hymn tunes for hymns based on the element of the service is needed. The essence and aspects of the service will also determine the hymn tune. The hymn leader should be cognizant of tunes suitable for a particular aspect of the worship. Learning at least a tune a week is necessary.

The hymn leaders should know the hymns in their denominational hymnal very well before leading the congregation. A song leader should not select or lead a hymn that he or she cannot sing. It should not be assumed that the congregation knows the hymn.

Dynamism is desirable in leading and singing hymns. For instance, hymn stanzas can be read, descant, canon, call and response, and application of dynamics can be applied. Likewise, females can be asked to sing a stanza and males could be asked to sing another stanza. All these bring dynamism to the congregational hymn singing.

In the same vein, where churches cannot afford paid musicians or theologically and musically trained ministers of music, the song leaders, instrumentalists, and singers should attend occasional music and worship workshops to aid their knowledge of hymns and church musicianship in general. Congregational hymn leading requires knowledge and dexterity. With basic knowledge of conducting patterns, the song leader would gain competence in congregational hymn leading.

Above all, it must be emphasized that there are two dimensions to hymn usage in the congregation. In some settings, the priest selects the hymns, in some other contexts it is the duty of the organist. In some other denominations, a Pastor who is equally a Minister of music selects the hymns. Where the song leader selects the songs, the aforementioned suggestions should be considered. Where the priest selects the hymns for the worship service, efforts and arrangements can be made between the priest and the song leader for the music unit to have access to the hymns for rehearsal at least a day before the worship service. 


\section{CONCLUSION}

This study has examined and reaffirmed the position of the hymn in worship and the role of song leaders in selecting and leading hymns. There are strong emphases on the factors to consider in selecting and leading hymns to stimulate congregational participation during corporate Christian worship. The compelling and persuasive argument in this study is that inadequate preparation and planning of the song leaders can impede good congregational hymn singing. Planning and knowledge of hymnody are sacrosanct to good hymn leading. Notably, planning, selection, and leading of hymns are intellectual and spiritual exercises that require at least, basic knowledge of music rudiment, knowledge of hymnody and prayer. It is hoped that future researchers would consider the necessary conducting patterns essential for hymn leading and the attitude of the congregation as it affects the leading of hymn singing in corporate Christian worship.

\section{ABOUT AUTHOR}

Adeolu Ogunleye, an ordained Baptist Minister holds a DMA in Church Music from the Nigerian Baptist Theological Seminary, Ogbomoso, Nigeria and he currently serves as the Minister of Music, Good News Baptist Church, Surulere, Lagos, Nigeria.

\section{BIBLIOGRAPHY}

Adeleke, A. Parameter for Using Music in Worship. Ibadan:Titles Publishers, 2014.

Carter, J. 9 Things You Should Know About Christian Hymns. Accesed May 14, 2021, https://www.thegospelcoalition.org/article/9-things... 2018.

Daramola, Y. "Christian Music as a Discipline: A Religious Appraisal of Christian Music in Nigeria Today". In CyberJournal for Pentecostal- Charismatic Research \#7, Accessed May 14, 2021, https://guardian.ng/art/night-of-unlimited-praise-in-1... n.d.

Davidson, P.O. "The Place of Music in Dialogical Worship". 1999 Ministers' Conference. Ogbomoso: Nigerian Baptist Theological Seminary, 1999. Come Let Us Worship.(Ibadan: Publication Department, Nigerian Baptist Convention, 2002).

Eskew, H. \& McElrath, H. Sing With Understanding. Nashville, Tennessee: Broadman Press, 1995.

Hollis B. Introduction to Conducting. Accessed April 21, 2017, https://method-behind-the-music.com/conducting/intro/.

"How to Plan Worship". Accessed April 3, 2018, www.movement.org/resources/ho.

"How to Plan Worship". Accessed April 3, 2018. http://www.crosswalk.com/church/cr.

"Hymnology". Encyclopedia.com. Accessed May 9, 2021, https://www.encyclopedia.com/religion/hymnology.

"Hymnology". Definition of Hymnody at Dictionary.com. Accessed June 8, 2021. https://www.dictionary.com/browse/hymnology.

Janvier, G.E. Leading the Church in Music \& Worship. Kaduna: Baraka Press and Publishers Ltd, 2007.

Kenedy, M. Oxford Concise Dictionary of Music. (Oxford: Oxford University Press, 2007).n.p.

Ogunleye, A.A. ed. Singing With Grace: Good News Baptist Church, Discipleship Study on Choir and Worship. Lagos: Benji and Associate, 2018.

Olajide, F. God is Hungry, Feed Him. Abeokuta: Dareg Image, 2018.

Rainer, T.S. CEO. Baptist Hymnal. Nashville: Tennessee: Lifeway worship, 2008.

Rohm A.H. Music for the Church. Ibadan: Dybis Limited, 1998.

Sim, H. "Planning Worship Music". In The Church Musicians. No.4. n.p.1965.

"5 Things to Avoid When Selecting Worship Songs". Accessed April 3, 2018. http://sharefaith.com/2013/10.

"10 Steps to Picking Songs for Your Worship Service”. Accessed April 3, 2018. http://www.sharefaith.com/2013/09.

"Worship Planning Process". Accessed April 3, 2018. http://worship.calvin.edu/resources. 